\title{
Hubungan Penguatan Modal Sosial, Mitigasi Bencana Banjir dan Peningkatan Produksi Pertanian
}

\author{
Sudirah $^{1}$, Agus Susanto ${ }^{2}$, Sumartono ${ }^{3}$, Muhammad Syukur ${ }^{4}$ \\ ${ }^{1}$ Program Studi Sosiologi, Universitas Terbuka \\ Email: sudi@ecampus.ut.ac.id \\ ${ }^{2}$ Program Studi Perencanaan Wilayah dan Kota, Universitas Terbuka \\ Email: sugus@ecampus.ut.ac.id \\ ${ }^{3}$ Program Studi Perencanaan Wilayah dan Kota, Universitas Terbuka \\ Email: sumartono@ecampus.ut.ac.id \\ ${ }^{4}$ Program Studi Pendidikan Sosiologi, Fakultas IImu Sosial, Universitas Negeri Makassar \\ Email:m.syukur@unm.ac.id
}

\begin{abstract}
Since the New Order until the reform era, sustainable rural development has continued to be carried out, one of which is the relationship between strengthening social capital and flood disaster mitigation, through studies from a sociological perspective and development counseling. The study was conducted in the villages of Kertawinangun, Soge, and Ilir, Indramayu district, West Java. In general, the rice planting season is carried out in the rendeng and sadon seasons. However, the rice planting season in the three villages can only be done in the rendeng season. Even then, they often experience crop failure (puso), due to flooding in the rainy season and drought in the dry season. The solution to the failed rice harvest was to build Kali Perawan weir. Weir construction needs financial capital and social capital. Social capital is the glue of social relations in the form of aspects: cultural wisdom, values, mutual cooperation, trust, and social networking. Strengthening social capital is facilitated by the Village Head, Village Consultative Body (BPD, and community leaders. This research method is descriptive qualitative. Collecting data through observation, documents, and interviews with informants. Data analysis was performed by triangulation. The results showed that strengthening social capital could strengthen community social relations, overcome flood disaster mitigation, and improve agricultural businesses, so that rice farmers enjoyed harvests 2 to 3 times a year. Biside that, it can carry out agricultural diversification by planting palawija, fish farming, and salt making, which can ultimately improve the welfare of farmers.
\end{abstract}

Keywords : Social Capital, Flood Disaster Mitigation, Increasing of Farmers' Welfare

Abstrak. Sudirah. Sejak Orde Baru hingga era reformasi ini pembangunan pedesaan berkelanjutan terus dilakukan salah satunya adalah hubungan antara penguatan modal sosial dan mitigasi bencana banjir, melalui kajian dari perspektif sosiologi dan penyuluhan pembangunan. Penelitian dilakukan di desa Kertawinangun, Soge, dan Ilir, kabupaten Indramayu, Jawa Barat. Pada umumnya musim tanam padi dilakukan pada musim rendeng dan sadon. Namun musim tanam padi di ketiga desa tersebut hanya dapat dilakukan pada musim rendeng. Itupun sering mengalami gagal panen (puso), akibat banjir pada musim hujan dan kekeringan pada musim kemarau. Solusi gagal panen padi tersebut adalah membangun bendung Kali Perawan. Pembangunan bendung perlu modal finansial dan modal sosial. Modal sosial merupakan perekat hubungan sosial masyarakat berupa aspek-aspek: kearifan budaya, tata nilai, gotong royong, kepercayaan, dan jejaring sosial. Penguatan modal sosial difasilitasi Kepala Desa, Badan Permusyawaratan Desa (BPD), dan tokoh-tokoh masyarakat. Metode penelitian ini adalah diskriptif kualitatif. Pengumpalan data melalui observasi, dokumen, dan wawancara terhadap informan. Analisis data dilakukan dengan triangulasi. Hasil penelitian menunjukkan bahwa penguatan modal sosial mampu merekatkan hubungan sosial masyarakat, mengatasi mitigasi bencana banjir, dan meningkatkan usaha pertanian, sehingga petani padi sawah menikmati hasil panen 2 sampai 3 kali setahun. Selain itu, dapat melakukan usaha diversifikasi pertanian dengan menanam palawija, usaha pertambakan ikan, dan pembuatan garam, yang akhirnya mampu meningkatkan kesejahteraan petani.

Kata Kunci : Modal Sosial, Mitigasi Bencana Banjir, Peningkatan Kesejahteraan Petani 


\section{PENDAHULUAN}

Mitigasi bencana banjir merupakan upaya-upaya yang dilakukan oleh masyarakat dan instansi yang terkait untuk mengurangi risiko bencana banjir. Upaya tersebut dapat dilakukan melalui pembangunan fisik, penyadaran akibat banjir, dan peningkatan kemampuan segenap lapisan masyarakat dalam menghadapi ancaman bencana (Pasal 1 ayat 6 PP No 21 Tahun 2008 tentang Penyelenggaraan Penanggulangan Bencana). Daerah yang kerap mengalami bencana banjir adalah daerah yang dilalui aliran sungai. Di Kabupaten Indramayu salah satu sungai yang sering menimbulkan banjir adalah Kali Perawan, yang membentang dari hulu desa Drunten (kecamatan Gabuswetan) ke hilir desa Eretan (kecamatan Kandanghaur), melalui desa Margamulya (kecamatan Bongas), dan Soge (kecamatan Kandanghaur), berjarak sekitar $15 \mathrm{~km}$. Lebar kali berkisar antara 50 meter di daerah hulu dan 100 m di daerah hilir. Dengan demikian Kali Perawan ini melintasi 3 kecamatan, yaitu Gabuswetan, Bongas, dan Kandanghaur.

Kali Perawan, pada musim penghujan berlangsung kerap menimbulkan banjir, sebaliknya ketika musim kemarau dapat menimbulkan kekeringan. Akibat kedua musim yang ekstrim tersebut dapat menimbulkan gagal panen (puso) bagi para petani yang lahan pertaniannya di daerah sekitar Kali Perawan. Berbagai upaya telah dilakukan untuk mengatasi bencana banjir tersebut, diantaranya adalah: penataan daerah aliran Kali Perawan, seperti normalisasi yaitu dengan meluruskan aliran yang berliku-liku agar aliran air tidak menggenang, dan cepat mengalir ke daerah hilir. Selain itu, pengerukan Kali Perawan yang mengalami pendangkalan juga dilakukan untuk memperdalam agar dapat menampung debit air lebih besar. Demikian juga penghijauan di daerah hulu untuk mencegah longsor dan membantu penyerapan air hujan ke tanah secara alami. Dan dari aspek kelembagaan melalui Dinas Pengairan Kabupaten Indramayu, membuat peraturan yang berupa larangan kepada warga masyarakat untuk tidak membuat bangunan di bantaran Kali Perawan.

Upaya-upaya mitigasi bencana banjir tersebut dapat membantu mengurangi bencana banjir. Meski demikian, pemanfaatan air Kali Perawan untuk pertanian padi sawah di daerah sekitar bantaran aliran kali tersebut belum dapat dilakukan dengan sebaik-baiknya. Air Kali Perawan meluap di waktu musim hujan dan kekeringan di waktu musim kemarau. Akibat kekeringan Kali Perawan tersebut terjadi intrusi air laut sepanjang $5 \mathrm{~km}$.

Untuk memanfaatkan air Kali Perawan tersebut bagi pertanian, dan mengurangi risiko banjir serta kekeringan salah satunya yaitu dengan pemanenan air hujan (rainwater harvesting) melalui pembangunan bendung Kali Perawan. Pembanguan bendung tersebut merupakan upaya pemerintah dan partisipasi masyarakat. Oleh karena itu diperlukan pendekatan modal sosial yang terdiri dari: trust, jejaring sosial, tata nilai, dan gotong-royong. Dengan demikian diperlukan penelitian secara kualitatif modal sosial di bantaran Kali Perawan tersebut, sehingga dapat diketahui sejauh mana peran modal sosial guna mitigasi banjir dan peningkatan produktivitas pertanian.

Ada berbagai definisi tentang modal sosial. Putnam (2002) mengemukakan modal sosial merupakan karakteristik, seperti kepercayaan, norma, dan jejaring sosial yang dimiliki organisasi sosial untuk memperbaiki kehidupan masyarakat melalui aktivitas yang terorganisasi. Bourdieu (1992) mengemukakan modal sosial merupakan totalitas dari semua sumber daya bersifat aktual ataupun nyata yang semakin meningkat jumlahnya kepada individu ataupun kelompok terkait dengan meluasnya jaringan sosial yang dilakukannya. Fukuyama (2000) mengemukakan modal sosial merupakan norma informal yang mendorong terjadinya relasi manusia di antara dua orang atau lebih. Relasi manusia tersebut didasarkan pada norma informal, dalam hubungan yang erat, dan hubungannya bersifat timbal balik (resiprositas). Sedangkan menurut Dasgupta (2003) modal sosial merupakan aturan sosial yang merekatkan masyarakat untuk senantiasa bersama dalam aktivitas kehidupannya. Dalam hal ini aturan sosial selaras dengan keberfungsian budaya masyarakat. Aturan sosial mendasari perasaan saling memiliki tentang budaya yang ada di masyarakat, dan aturan sosial mendasari perasaan sepenanggungan dalam kehidupan sosialnya.

Selain itu, modal sosial merupakan alat untuk menyelesaikan konflik yang ada di dalam masyarakat, dan memberikan kontribusi bagi terjadinya integrasi sosial. Bahkan, modal sosial dapat 
membentuk solidaritas sosial masyarakat dengan pilar kesukarelaan, dan membangun partisipasi masyarakat. Sebagai pilar demokrasi, modal sosial dapat menjadi instrumen untuk bargaining sesuatu dengan pemerintah.

Dari berbagai pendapat tersebut, dapat dirumuskan kembali bahwa modal sosial merupakan perekat hubungan sosial antar personal (interpersonal connection) melalui wadah, seperti kelembagaan atau jaringan sosial (social networks). Hubungan sosial tersebut didasarkan pada norma perilaku bersama (shared behavioral norms) yang berperan sebagai aturan sosial bersama (social order) yang mendasari kehidupan sosialnya. Hubungan sosial tersebut juga dipererat oleh budaya bersama (cultural identifications) sebagai pengikat perasaan saling memiliki dan sepenanggungan (sense of belonging), sehingga terjaga kelestarian, kesatuan dan kebersamaan. Semua itu ditujukan untuk mencapai kesejahteraan sosial, sebagai tujuan bersama.

Kini dalam perkembangannya, modal sosial mampu merekatkan, dan mempersatukan hubungan sosial individu, kelompok, komunitas, masyarakat, termasuk masyarakat petani padi sawah. Dalam tataran sosiologis, modal sosial itu berupa tata nilai (norms), ada hubungan timbal balik, dan saling mempercayai antar dua pihak atau lebih, yang dapat diwujudkan dalam hubungan yang sangat erat (pertemanan) bukan hubungan formal, yang ditujukan untuk mencapai kesejahteraan sosial bersama.

Sebagai perekat hubungan sosial masyarakat, modal sosial mencakup unsur-unsur kearifan budaya, tata nilai, gotong-royong, membangun saling kepercayaan (trust), dan jaringan sosial yang dapat digambarkan sebagai berikut.

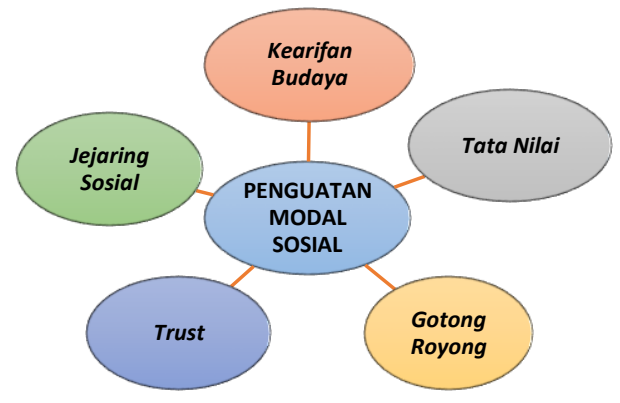

Gambar 1. Faktor-faktor yang mendukung Penguatan Modal Sosial (Fukuyama, 2000; Bourdieu, 1992; Fukuyama, 2000; Dasgupta, 2003), diadaptasi kembali.

Inti dari mitigasi bencana banjir adalah upaya mencegah dan menanggulangi bencana banjir yang dilakukan oleh masyarakat bersama lembaga-lembaga desa, dan instansi yang terkait dengan membangun infrastruktur perairan seperti bendung, dan saluran irigasi (Sudirah, 2019). Dengan membangun bendung dan saluran irigasi mampu mengatasi dan menanggulangi kegagalan panen para petani, yang dapat digambarkan sebagai berikut.

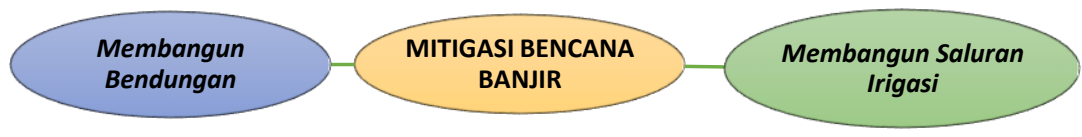

Gambar 2. Mitigasi Bencana Banjir

Peningkatan produksi pertanian padi sawah dilakukan dengan penguatan kelembagaan pengairan, intensifikasi dan ekstensifikasi pertanian, serta meningkatkan diversifikasi pertanian (Sudirah, 2019). Peningkatan produksi pertanian tersebut dapat digambarkan sebagai berikut. 


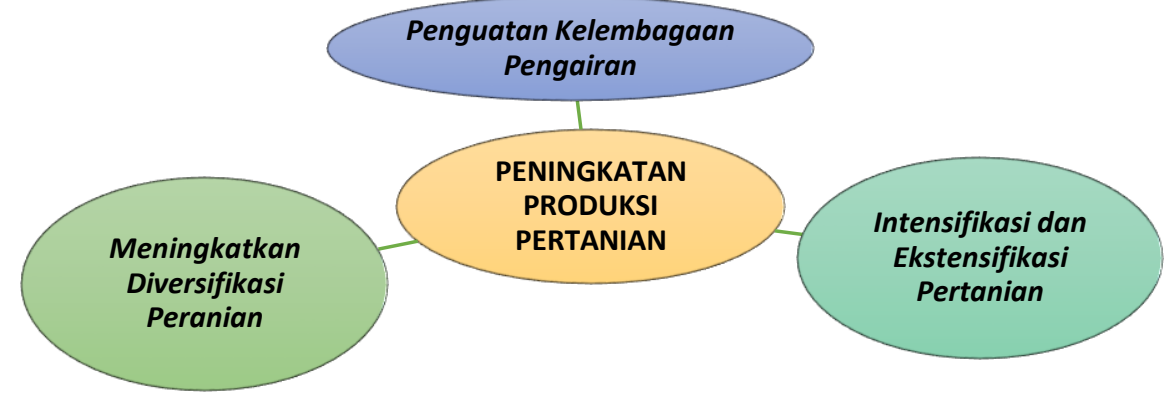

Gambar 3. Peningkatan Produksi Pertanian

Keterkaitan penguatan modal sosial, mitigasi bencana banjir, dan peningkatan produksi pertanian dapat digambarkan sebagai berikut:

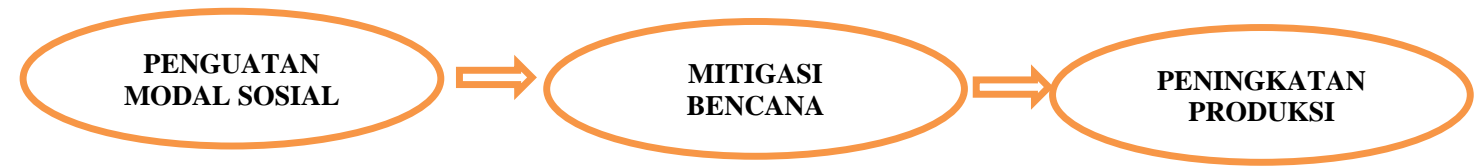

Gambar 4. Penguatan Modal Sosial, Mitigasi Bencana Banjir, dan Peningkatan Produksi Pertanian

\section{METODE PENELITIAN}

Penelitian ini dilakukan di desa Kertawinangun, Soge, dan Ilir kecamatan Kandanghaur, Kabupaten Indramayu, Jawa Barat. Aspek-aspek yang menjadi fokus kajian dalam penelitian ini adalah modal sosial dan mitigasi bencana banjir. Fokus kajian yang berkenaan dengan aspek-aspek modal sosial adalah kearifan budaya, tata nilai, gotong-royong, membangun saling kepercayaan (trust), dan jejaring sosial. Sedangkan aspek yang berkenaan dengan mitigasi bencana banjir adalah pembangunan bendung, pembangunan saluran irigasi. Seluruh fokus tersebut dikaji berdasarkan data dan informasi yang diperoleh melalui metode kualitatif.

Pendekatan yang digunakan dalam penelitian ini adalah kualitatif. Pendekatan ini dipilih, karena untuk memperoleh data deskriptif atau data kualitatif yang lebih mendalam tentang aspek-aspek penguatan modal sosial, dan upaya-upaya dalam menanggulangi ancaman mitigasi bencana banjir pada masyarakat petani. Dalam menggali data dan informasi yang berkenaan dengan fokus kajian tersebut yaitu melalui observasi, wawancara, dan dokumentasi. Melalui observasi dilakukan pengamatan terhadap hal-hal yang berkenaan dengan kondisi daerah aliran Kali Perawan, ketersediaan air Kali Perawan, sistem saluran irigasi, wilayah persawahan, wilayah pertambakan, kondisi Bendung Karet Kali Perawan. Wawancara mendalam dilakukan dengan segenap informan, seperti petani, pengurus kontak tani, kepala desa, perangkat desa, lembaga sosial desa, pengurus P3A Mitra Cai, lembaga swadaya masyarakat (LSM) dan sebagainya. Pemilihan informan dilakukan secara random purposif. Dalam wawancara dengan informan dilakukan tidak hanya secara langsung, tetapi juga dilakukan melalui telepon. Selain itu, menggali dokumen untuk mendapatkan berbagai data dan informasi yang terkait dengan aspek-aspek kajian tersebut.

Teknik pengambilan data dilakukan melalui Focus Group Disscusion (FGD). Dalam hal ini, dilakukan panel antara pewawancara dengan narasumber (petani, pengurus kontak tani, perangkat desa, lembaga permusyawaratan desa, petugas pengairan, dan LSM). Langkah terakhir yang dilakukan adalah dengan tanya jawab dan diskusi untuk mengkaji aspek-aspek modal sosial dan mitigasi bencana banjir.

Analisis data dilakukan dengan menggunakan triangulasi. Analisis triangulasi adalah melakukan verifikasi hal-hal yang berkenaan dengan data dan informasi yang diperoleh, teori yang dirujuk, metode penelitian yang digunakan, dan pendapat antar peneliti. Pada triangulasi, data dan informasi, 
terlebih dahulu dilakukan klasifikasi data menjadi data primer dan data sekunder, data kuantitatif dan data kualitatif. Konfirmasi data dilakukan dengan meminta pendapat informan kembali. Konfirmasi dengan informan dilakukan dengan meminta pendapat informan lainnya tentang hal yang sama sebagai pembanding sehingga menjadi lebih jelas tentang data tersebut. Langkah selanjutnya adalah melakukan klasifikasi kembali berdasarkan indikator-indikator aspek yang dikaji. Dalam melakukan proses analisis ini secara simultan dilakukan konfirmasi data kembali kepada responden dan narasumber.

Analisis triangulasi selanjutnya yaitu dengan membandingkan konsep ataupun teori yang menjadi rujukan dengan fakta-fakta di lapangan. Membandingkan konsep ataupun teori dengan fakta dilakukan untuk melihat konsistensi antara konsep ataupun teori dengan fakta di lapangan. Dari hasil analisis triangulasi teori ternyata dapat mengkonfirmasi tentang fakta-fakta di lapangan, dan mengkonfirmasi tentang teori-teori yang menjadi rujukan. Dari hasil analisis triangulasi, teori-teori yang menjadi rujukan mampu menjelaskan fakta-fakta di lapangan. Selanjutnya, melakukan analisis triangulasi yang berkenaan dengan metode penelitian yang digunakan. Hasil triangulasi menunjukkan bahwa metode kualitatif yang digunakan sudah tepat sebagai pendekatan untuk menjelaskan fenomena permasalahan penelitian ini.

Langkah selanjutnya dalam triangulasi yang berkenaan dengan pendapat antar peneliti lain. Hal ini dilakukan dengan peneliti sejawat, peneliti bidang lain yang relevan, dan dari segi ilmu masih serumpun. Dari hasil triangulaisi ini, diperoleh pemahaman yang lebih komprehensif tentang aspekaspek yang berkenaan dengan penguatan modal sosial, mitigasi bencana banjir, dan peningkatan produksi pertanian di lapangan. Langkah terakhir sebelum mengambil kesimpulan, dilakukan konfirmasi temuan penelitian dengan sejumlah informan di lapangan. Penarikan kesimpulan baru diambil setelah melalui serangkaian analisis triangulasi tersebut.

\section{HASIL DAN PEMBAHASAN}

Modal sosial perlu penguatan. Penguatan modal sosial dapat mendorong mitigasi bencana banjir. Selanjutnya mitigasi bencana banjir dapat meningkatkan produksi pertanian. Karena itu pembahasan akan difokuskan pada penguatan modal sosial masyarakat petani padi sawah, mitigasi bencana banjir, dan peningkatan produksi pertanian sebagai berikut.

\section{Penguatan Modal Sosial Masyarakat Petani Padi Sawah}

Penguatan modal sosial masyarakat padi sawah dilakukan melalui penguatan kapasitas diri petani, dan koordinasi kelembagaan desa bersama masyarakat petani. Peran kepala desa dalam hal ini sangat penting untuk memandu urun rembug, pertemuan, dan koordinasi antara para petani, dan kelembagaan desa yang terkait. Dalam urun rembug tersebut pembahasan difokuskan pada modal sosial dan mitigasi bencana banjir, sebagai berikut.

\section{a) Kapasitas Masyarakat Petani Padi Sawah}

Penguatan modal sosial bagi para petani di lokasi penelitian ini ditujukan untuk meningkatkan kapasitas diri mereka tentang pemantapan aturan sosial, pemahaman bertani padi sawah, seluk beluk usaha tani, pelestarian warisan budaya bercocok tanam, pengembangan usaha pertanian, diversifikasi usaha tani, dan sebagainya. Penguatan modal sosial tersebut dapat dilakukan melalui penyuluhan, pendampingan, bimbingan masyarakat, sosialisasi, dan sebagainya oleh instansi ataupun lembaga sosial terkait dengan melibatkan masyarakat dan tokoh-tokoh masyarakat setempat, secara formal maupun informal.

Penyuluhan tentang tata nilai yang berkenaan dengan usaha pertanian, khususnya bercocok tanam padi dan palawija tersebut sudah diwariskan dari generasi ke genarasi. Sistem bercocok tanam padi yang demikian sudah menjadi budaya masyarakat agraris di ketiga desa tersebut. Sistem bercocok tanam padi yang demikian dibangun dan dikerjakan secara bergotong-royong dengan melibatkan segenap anggota masyarakat. 
Melalui penyuluhan dan kegiatan serupa lainnya tersebut masyarakat petani padi sawah memahami dan menghayati nilai-nilai modal sosial tersebut untuk diimplementasikan dalam berusaha dan bekerja di lingkungan sosial masyarakatnya (Pranadji, 2006). Penguatan modal sosial difasilitasi, dan dipandu kepala desa untuk urun rembug antara para petani dengan kelembagan desa lainnya untuk mendorong terwujudnya pembangunan Bendung Karet. Kepala desa juga berkoordinasi dengan P3A Mitra Cai untuk berpartisipasi aktif mengawal dan mendistribusikan sistem pengairan irigasi dari Bendung Karet Kali Perawan ke lahan sawah petani di desa-desa tersebut.

\section{b) Koordinasi Kelembagaan Desa bersama Masyarakat Petani Padi sawah}

Koordinasi merupakan hal penting dalam upaya mempersatukan, mempertemukan segenap pihak yang terkait untuk mencapai tujuan bersama. Peran kepala desa dalam hal ini sangat penting untuk mampu menggerakkan kelembagaan desa yang ada, bersama segenap masyarakat mencari solusi untuk memecahkan permasalahan banjir yang dialami masyarakat petani. Melalui urun rembug yang dipandu kepala desa, semua pihak yang terkait dengan mitigasi bencana banjir, dan mencari solusi terhadap permasalahan yang dihadapinya. Beberapa kali pertemuan antara kepala desa bersama para petani, pengurus kontak tani, perangkat desa, lembaga sosial desa, pengurus P3A Mitra Cai, lembaga swadaya masyarakat (LSM) dan sebagainya itu digelar untuk menyatukan pemikiran dan tindakan untuk mengatasi bencana banjir tersebut. Akhirnya disepakati bahwa membangun Bendung Karet Kali Perawan, bersama saluran irigasinya merupakan solusi yang tepat untuk mengatasi bencana banjir yang dialami masyarakat petani di daerahnya.

Kerjasama yang demikian terjalin melalui suatu jaringan kerjasama yang baik. Membangun saling kepercayaan sesama para petani, maupun dengan pihak pemerintah (Dinas Pertanian, Dinas PU). Semua itu menjadi perekat hubungan sosial para komunitas petani. Penguatan modal sosial tersebut dibangun melaui kerjasama dengan instansi yang terkait. Sejak pemerintahan orde baru, sistem pertanian di wilayah Indramayu terus mengalami kemajuan. Sejumlah bendung telah di bangun, sistem irigasi ditata, sehingga sejak tahun 2010 Kabupaten Indramayu menyusul Kabupaten Kerawang sebagai daerah lumbung padi bagi Jawa Barat. Dari data yang dikeluarkan Badan Pusat Statistik Jawa Barat, produksi padi yang dihasilkan petani Indramayu sejak tahun 2010 hingga tahun 2015 sekitar 1,2 hingga 1,4 juta ton per tahun. Kemudian pada tahun 2018 produksi padi di Indramayu meningkat sekitar 1,4 juta ton per tahun (BPS Jawa Barat, 2018).

\section{Mitigasi Bencana Banjir Kali Perawan}

Mitigasi bencana adalah serangkaian upaya yang dilakukan oleh instansi yang terkait bersama masyarakat untuk mengurangi risiko bencana, baik melalui pembangunan fisik maupun penyadaran tentang akibat bencana banjir, dan peningkatan kemampuan menghadapi ancaman bencana (Pasal 1 ayat 6 PP No 21 Tahun 2008 Tentang Penyelenggaraan Penanggulangan Bencana). Dalam menanggulangi permasalahan banjir di kawasan Kali Perawan, ada 4 (empat) upaya yang sudah dilakukan oleh Pemerintah Daerah di sana, yaitu: (a) penataan daerah aliran sungai, (b) tidak membangun bangunan di bantaran sungai, (c) pengerukan sungai, dan (d) penghijauan hulu sungai.

Penataan daerah aliran sungai dilakukan dengan cara membangun "baro" (pagar balok kayu) di sejumlah tempat yang kritis longsor di sepanjang Kali Perawan. Tanggul kali yang berbatasan langsung dengan Kali Perawan di pasang "baro" untuk mencegah longsornya tanggul ke sungai. "Baro" juga berfungsi untuk menahan arus derasnya air sungai yang meluap pada saat banjir, sehingga air banjir tidak langsung menggerus tanggul yang dapat mengakibatkan tanggul jebol.

Masyarakat juga dilarang untuk tidak membangun bangunan di bantaran sungai. Bangunan (gubuk-gubuk) yang ada di sepanjang bantaran Kali Perawan dibersihkan. Demikian pula pohon-pohon besar yang tumbuh di sepanjang bantaran Kali Parawan di potong. Meski demikian masih ada sejumlah warga yang memanfaatkan bantaran kali Perawan ini untuk menanam palawija, seperti kacang panjang, kacang tanah, timun, cabe rawit, cabe keriting, dan sebagainya. Bahkan ada juga yang menanam padi di bantaran Kali Perawan tersebut. Sepertinya ada kerjasama antara petani yang memanfaatkan bantaran Kali Perawan yang menanam palawija dengan seksi pengairan setempat. 
Petugas pengairan memungut sewa bantaran Kali Perawan tersebut kepada penggarap lahan bantaran kali tersebut setiap tahunnya.

Di beberapa lokasi Kali Perawan mengalami pendangkalan, akibat pengendapan lumpur (sedimentasi). Pengerukan sungai dilakukan untuk lokasi-lokasi sungai yang mengalami pendangkalan tersebut. Pengerukan dilakukan oleh instansi terkait, seperti dinas pekerjaan umum. Dengan demikian, sungai menjadi lebih dalam, dapat menampung debit air sungai lebih banyak, dan dapat memperlancar jalannya arus sungai dari hulu ke hilir sungai.

Di daerah hulu Kali Perawan tumbuh sejumlah pohon dari berbagai jenis. Pohon-pohon tersebut ditanam penduduk sekitar yang mengelola lahan hulu sungai tersebut. Apabila mereka membutuhkan pohon warga penduduk melakukan penebangan sehingga tanah menjadi gersang. Akibatnya penyerapan air hujan pada musim hujan kurang maksimal, mudah menimbulkan banjir, dan rawan terhadap kemungkinan terjadinya longsor di tempat-tempat yang jurang. Penghijauan daerah hulu Kali Perawan sudah dilakukan, namun kelestariannya masih perlu dijaga secara terus menerus. Himbauan, dan penyuluhan tentang pentingnya melestarikan kawasan penghijauan daerah hulu Kali Perawan kepada warga masyarakat sekitar perlu dilakukan secara terus menerus.

\section{a) Membangun Bendung Karet Kali Perawan}

Masalah utama pertanian padi sawah yang dihadapi oleh 3 desa, yaitu desa Soge, Kertawinangun dan Ilir kecamatan Kandanghaur kabupaten Indramayu adalah kekurangan air untuk pertanian padi. Sepatutnya sistem pertanian yang baik adalah tersedia sistem irigasi pengairan yang baik. Sebaliknya kondisi di lapangan adalah sering banjir pada musim hujan dan kekeringan pada musim kemarau. Akibat banjir tanaman padi mati. Tanaman padi itu mati karena rendaman banjir lebih dari tiga hari. Durasi rendaman yang lama membuat tanaman padi membusuk dan mati. Akibatnya, petani harus menanam ulang padi.

Selain itu akibat kekeringan tersebut masyarakat petani kekurangan air untuk pertaniannya. Karena itu masyarakat pertanian membutuhkan pengairan dan saluran irigasi untuk usaha pertaniannya. Melalui badan permusyawaratan desa (BPD) masyarakat mengusulkan kepada kepala desa (kuwu) untuk mengatasi permasalahan kekurangan air pertanian padi tersebut. Setelah berkoordinasi dengan Camat Kandanghaur selaku atasannya, selanjutnya aspirasi masyarakat di tiga desa tersebut oleh kepala desa diteruskan kepada Wakil Rakyat di tingkat DPRD maupun DPR Pusat. Setelah melalui usaha dan perjuangan yang panjang dilakukan oleh masyarakat bersama kepala desa, para wakil rakyat, akhirnya pembangunan Bendung Karet Kali Perawan dapat terwujud. Pembangunan Bendung Karet dikerjakan Balai Besar Wilayah Sungai (BBWS) Citarum, Ditjen Sumber Daya Air. Bendung Karet diresmikan Presiden Jokowi pada 9 November 2018. Menteri Pekerjaan Umum dan Perumahan Rakyat (PUPR) Basuki Hadimuljono, mengatakan pembangunan bendung karet seperti ini merupakan salah satu cara yang cukup efektif dan efisien untuk pengelolaan air tawar. "Pembangunan bendung tidak membutuhkan pembebasan lahan karena menggunakan badan sungai itu sendiri. Desain dan konstruksinya lebih sederhana dibanding pembangunan bendungan. Biayanya pun lebih kecil. Untuk Bendung Karet Kali Perawan sebesar Rp 67,4 miliar," (siaran pers saat peresmian Bendung Karet Kali Perawan 9/11/2018). Bendung karet ini mampu mengatasi risiko banjir di 3 (tiga) desa seluas 380 ha, yakni Desa Soge, Kertawinangun, dan Ilir, kecamatan Kandanghaur, kabupaten Indramayu (Prabowo, 2018). 


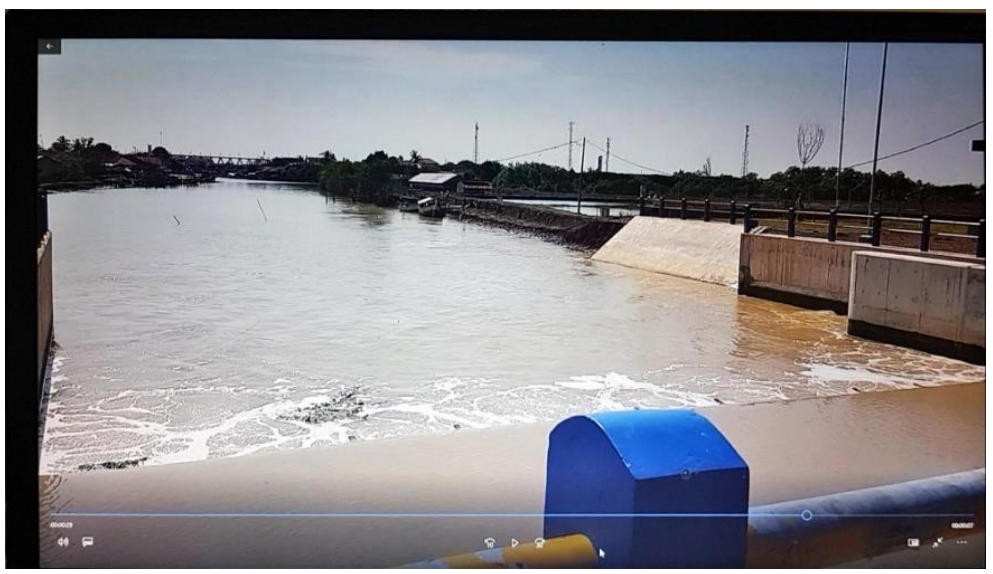

Foto 1.

Bendung Karet Kali Perawan di Desa Soge, Indramayu

\section{b) Membangun Saluran Irigasi dari Bendung Karet Kali Perawan ke Persawahan}

Setidaknya ada 2 (dua) fungsi utama Bendung Karet Kali Perawan, yaitu pertama, untuk mengatasi bencana banjir pada musim hujan dan intrusi air laut yang datang dari hulu Kali Perawan di Eretan pantai utara Indramayu Jawa Barat. Fungsi kedua adalah sebagai tempat penyimpanan air atau long storage yang dapat dimanfaatkan sebagai sumber pengairan pertanian pada musim kemarau. Pada saat musim kemarau, pintu bendung ditutup sehingga menjadi long storage yang bisa menampung air lebih dari 1 juta meter kubik dan sekaligus mencegah intrusi air laut ke sungai.

Sementara pada musim hujan, pintu bendung akan ditutup hingga ketinggian air mencapai elevasi 1,9 meter, yang kemudian dialirkan ke laut dengan kapasitas $255,18 \mathrm{~m}^{3}$ per detik. Dengan tetap terjaganya debit air di sungai tersebut, maka dapat digunakan untuk mengairi daerah irigasi seluas 2.307 ha dan diharapkan dapat membantu peningkatan jumlah panen dari 2 kali menjadi 3 kali panen dalam setahun.

Selain itu, para petani memanfaatkan bendung karet ini untuk mengairi daerah perikanan air tawar seluas 200 ha. Untuk mengakomodir kebutuhan para petani garam, dibuat saluran khusus mengalirkan air laut ke tambak-tambak garam sepanjang $1 \mathrm{~km}$. Kepala BBWS Citarum, Bob Arthur Lombogia menyatakan, pengerjaan proyek pembangunan bendung karet tersebut dilakukan sejak Maret 2017 hingga Oktober 2018. Pekerjaan dilaksanakan oleh kontraktor PT PP (Persero) Tbk. Bendung karet dengan pelindung baja sepanjang 22 meter memiliki kelebihan pada masa umur pakai karet yang lebih lama karena terlindungi panel baja. Selain itu, waktu untuk menaikkan dan menurunkan muka air lebih cepat dari pada bendung karet tanpa panel baja dan dapat dioperasikan sesuai kebutuhan atau elevasi muka air yang diinginkan.

\section{Peningkatan Produksi Pertanian Padi sawah}

Peningkatan produksi pertanian, perlu ditunjang oleh penguatan kelembagan pengairan, peningkatan intensifikasi dan ekstensifikasi pertanian, serta peningkatan diversifikasi pertanian.

\section{a) Penguatan Kelembagaan Pengairan Pertanian Padi Sawah}

Kelembagaan pengairan yang terkait dengan pertanian padi di kawasan Bendung Kali Perawan adalah Perkumpulan Petani Pemakai Air (P3A) Mitra Cai. Lembaga pengairan ini adalah wadah untuk menampung kepentingan dan kegiatan petani secara bersama dalam mengelola air irigasi serta usaha tani. P3A Mitra Cai dibentuk oleh dan atau untuk petani pemakai air di daerah irigasi berdasarkan kesadaran dan kepentingan bersama masyarakat petani. Anggota P3A Mitra Cai adalah para petani yang bersangkutan. Dalam pelaksanaan tugasnya P3A Mitra Cai dibantu oleh ulu-ulu sebagai pelaksana teknis sehari-hari dalam pengelolaan air irigasi di wilayah kerjanya. Petugas ulu-ulu mengawal dan mendistribusikan sistem pengairan dari irigasi ke sawah-sawah para petani (Perda DT II Indramayu No.17/1995 tentang P3A Mitra Cai).

Kondisi kelembagaan pengairan yang ada secara periodik ditingkatkan kemampuannya (penguatan kelembagaan). Penguatan kelembagaan pengairan P3A Mitra Cai dilakukan melalui 
pemberdayaan sumber daya para anggotanya. Dalam hal ini pemberdayaan P3A Mitra Cai mencakup aksesibilitas informasi, partisipasi masyarakat, akuntabilitas, dan peningkatan kapasitas anggota (Sudirah, 2016). Aksesibilitas informasi adalah faktor-faktor yang mendukung kemudahan akses informasi bagi petani padi, dan anggota P3A Mitra Cai untuk meningkatkan wawasan intelektualnya. Dengan demikian, mereka memahami kondisi usaha pertaniannya, sehingga dapat memilih bibit yang baik, pupuk yang berkualitas, mengembangkan pemasaran produk pertaniannya, dan mengembangkan usaha, dan sebagainya. Intinya, petani padi perlu memiliki wawasan intelektual untuk kemajuan dan pengembangan usaha pertaniannya.

Partisipasi masyarakat merupakan bentuk pelibatan berbagai sumber daya masyarakat untuk meningkatkan kapasitas diri yang diperlukan oleh petani padi. Kapasitas diri dapat dilakukan melalui pemantapan aturan sosial dengan melibatkan segenap sumber daya manusia (SDM) yang ada di masyarakat. Dengan demikian, penguatan kelembagaan pengairan sepatutnya melibatkan SDM yang ada di masyarakat sehingga para petani padi lebih berdaya dalam usaha maupun bekerja.

Akuntabilitas memiliki berbagai pengertian. Akuntabilitas merupakan bentuk pertanggunggugatan terhadap pihak-pihak yang berkepentingan. Dalam konteks penguatan kelembagaan pengairan, akuntabilitas dapat diartikan sebagai kewajiban petani padi untuk secara bersama-sama SDM yang ada di masyarakat mengambil peran tanggung jawab terhadap peningkatan kapasitas diri petani padi. Peningkatan kapasitas dapat dilakukan melalui sosialisasi, penyuluhan, pelatihan, dan pendampingan yang berkenaan dengan seluk beluk pertanian padi. Dengan demikian, para petani padi lebih berdaya dalam berusaha dan bekerja.

Penguatan kelembagaan pengairan pertanian memerlukan kelembagaan lokal yang handal. Dalam hal ini, selain P3A Mitra Cai, kelembagaan lokal lainnya seperti, koperasi, dan lembaga swadaya masyarakat (LSM) diharapkan memainkan peran penting dalam pengembangan kapasitas diri petani padi. Pelibatan kelembagaan lokal tersebut diharapkan mampu meningkatkan kemampuan dan keterampilan yang diperlukan dalam usaha maupun bekerja. Intinya kapasitas kelembagaan pengairan diharapkan mampu mengawal dan mendistribusikan sistem irigasi pengairan untuk kebutuhan para petani padi menjadi lebih maju dan berkembang usahanya.

\section{b) Intensifikasi Pertanian Padi Sawah}

Pembangunan Bendung Kali Perawan yang berlokasi di desa Soge mampu mengembangkan musim tanam dan sistem pertanian di desa Soge, Kertawinangun dan llir. Saat ini, musim tanam di ketiga desa tersebut dapat dilakukan 2 kali setahun, yaitu musim rendeng dan musim sadon, dengan tingkat produktivitas rata-rata sekitar 7 sampai 8 ton/ha/musim tanam. Sebelumnya lahan sawah di ketiga desa tersebut hanya dapat dilakukan 1 kali pada musim rendeng per tahun.

Pengembangan sistem pertanian di ketiga desa tersebut dilakukan dengan intensifikasi, yaitu pertanian dilakukan dengan mengoptimalkan pengolahan lahan sawah yang ada dengan menerapkan panca usaha tani, yaitu pengolahan tanah yang baik, irigasi yang teratur, pemilihan bibit unggul, pemupukan, dan pemberantasan hama dan penyakit tanaman. Air Kali Perawan yang sudah dibendung di Desa Soge tersebut dimanfaatkan dengan sebaik-baiknya oleh para petani untuk intensifikasi pertanian, yaitu dengan jalan menyedot air Kali Perawan dengan menggunakan mesin penyedot (pompa air), yang kemudian dialirkan ke lahan sawah di bantaran kali tersebut.

\section{c) Meningkatkan Diversifikasi Pertanian Palawija}

Pasca musim sadon para petani mulai melakukan diversifikasi pertanian. Para petani melakukan usaha penganekaragaman jenis pertanian yaitu dengan menanam palawija. Hal ini dilakukan untuk menghindari ketergantungan pada hasil pertanian padi sawah. Jenis palawija yang ditanam adalah bonteng (sejenis timun), waluh (labuh bulat), kukuk (waluh panjang), kacang panjang, pare, semangka, jagung, dan lainnya. Selain itu para petani juga melakukan usaha tambak ikan, yaitu dengan membuat tambak-tambak, seperti tambak ikan lele, gurame, dan sebagainya. Sebagian petani memanfaatkan lahan tersebut untuk usaha pembuatan garam, terutama pada musim kemarau. Semua itu dapat meningkatkan pendapatan petani dari usaha menanam palawija, dan pertambakan ikan, serta pembuatan garam. 


\section{KESIMPULAN}

Penguatan modal sosial petani padi sawah melalui kearifan budaya, tata nilai, gotong royong, membangun saling kepercayaan (trust), dan jejaring sosial berkontribusi terhadap mitigasi bencana banjir di bidang pertanian padi sawah. Mitigasi bencana banjir melalui pembangunan Bendung Karet Kali Perawan, dan pembangunan saluran irigasi mampu mengatasi bencana banjir pada musim hujan, kekeringan pada musim kemarau, dengan menampung debit air sungai di bendung tersebut. Selain itu, Pembangunan Saluran irigasi mampu mendistribusikan sistem pengairan irigasi padi sawah dari bendung tersebut ke seluruh persawahan di desa Soge, Kertawinangun, dan Ilir Kecamatan Kandanghaur Kabupaten Indramayu, sehingga petani dapat melaksanakan tanam padi 2 sampai 3 kali dalam 1 tahun. Mitigasi bencana banjir mampu meningkatkan produksi pertanian melalui intensifikasi dan ekstensifikasi pertanian, serta diversifikasi pertanian. Usaha-usaha diversifikasi pertanian tersebut meliputi usaha palawija, pertambakan ikan, dan pembuatan garam.

\section{DAFTAR PUSTAKA}

Badan Pusat Statistik (BPS) - Jawa Barat dalam Angka 2018.

Bourdieu, P. (1992). The Form of Capital. In J. Richardson (Ed). Handbook of Theory and Research for Sociology of Education. New York: Greenwood Press.

Fukuyama, Francis (2000). Trust: The Social Virtues and The Creation of Prosperity, New York: the Free Press Onyx, J (1996), "The Measure of Social Capital", paper presented to Australian and New Zealand Third Sector Research Conference on Social Cohesion, Justice and Citizenship: The Role of Voluntary Sector, Victoria University, Wellington.

Perda DT II Indramayu No.17/1995 tentang Pedoman Pembentukan dan Pengembangan Perkumpulan Petani Pemakai Air (P3A) Mitra Cai di Kab. DT II Indramayu.

Prabowo, Dani. (2018). Minimalisasi Banjir Indramayu Pemerintah Kebut Proyek Bendung Karet. https://properti.kompas.com/read/2018/11/12/220000821/minimalisasi-banjir-indramayupemerintah-kebut-proyek-bendung-karet. 12 November 2018.

Sudirah, Agus Susanto, Agus Santoso. (2019). Makalah: Penguatan Kelembagaan Desa dan Mitigasi Bencana Puso. Seminar Nasional FST-UT, Pondok Cabe, 3 Oktober 2019.

Sudirah. (2016). Makalah: Pemberdayaan Masyarakat Desa Wisata di Era Globalisasi. Seminar dan Simposium Nasional APSSI di Makasar 29-30 September 2016.

Sudirah. (2019). Makalah: Penguatan Modal sosial dan Mitigasi Bencana Puso. Konferensi Nasional Sosiologi VIII di Medan 31 Maret-2ril 2019.

\section{Sumber Jurnal}

Pranadji, Tri. (2006). Penguatan Modal Sosial untuk Pemberdayaan Masyarakat Pedesaan dalam Pengelolaan Agroekosistem Lahan Kering: Studi Kasus di Desa-desa (Hulu DAS) Ex Proyek Bangun Desa, Kab Gunungkidul dan Ex Proyek Pertanian Lahan Kering, Kab. Boyolali. Jurnal Agro Ekonomi. 24 (2). 178-208.

Putnam, RD. (2002). The Prosperous Community: Social Capital and Public Life, dalam The American Prospect, Vol.13, halaman 35-42. 